\title{
A simplified method for the evaluation of spermatogenesis in the guinea-pig
}

\author{
W. B. Panko*, D. E. Noller and S. S. Howards \\ Departments of Biochemistry, Urology and Physiology, \\ University of Virginia School of Medicine, \\ Charlottesville, Virginia, 22901, U.S.A.
}

The search for a male contraceptive agent has increased interest in the effect of pharmacological and endocrinological agents on spermatogenesis. A simple and quick method to assess spermatogenic activity would facilitate evaluation of such compounds. Conventional histological and autoradiographic techniques are time-consuming and difficult to quantitate.

One activity known to be associated with spermatogenesis is the replication of deoxyribonucleic acid (DNA) (Clermont \& Trott, 1969). Although DNA is replicated in many cells, the rate of DNA synthesis in most somatic cells, including the Sertoli cells, is rather low. However, the rate of DNA synthesis in spermatogonia is high and the aim of this study was to develop a measurement of DNA synthesis to serve as a fast and simple index of spermatogenesis.

The guinea-pigs were mature males of the Hartley strain. Twelve animals weighing about $580 \mathrm{~g}$ and 3 animals of about $980 \mathrm{~g}$ were killed as controls. Testicular parenchyma was extruded through the tunica albuginea, weighed and some of it was processed for histology and autoradiography. The remaining parenchyma (weighed) was homogenized in 5 volumes of distilled water. Macromolecular fractions were isolated by the method of Hutchinson \& Munro (1961) and the concentrations of RNA, DNA and protein were determined by the methods of Schneider (1945), Burton (1956) and Lowry, Rosebrough, Farr \& Randall (1951), respectively. The testicular concentrations of RNA and DNA in guinea-pigs are higher (Table 1) than those reported for other species, e.g. mean values for RNA in gerbil and rat testis are 3.82 (Lohiya \& Dixit, 1974) and 2.75 (Kwart \& Coffey, 1973) $\mathrm{mg} / \mathrm{g}$ wet weight, and for DNA are $1.56 \mathrm{mg} / \mathrm{g}$ wet weight in rat testis (Kwart \& Coffey, 1973). This may be a characteristic of guinea-pig testis or may be due to variations in technique. These values for DNA and RNA concentration are consistent with values reported for rat kidney (Janicki \& Lingis, 1970). Also, DNA was hydrolysed for analysis at a temperature of $70^{\circ} \mathrm{C}$ which gave a better recovery for testicular DNA than the higher temperatures usually used (D. W. Noller \& W. B. Panko, unpublished results).

Table 1. The concentrations ( $\mathrm{mg} / \mathrm{g}$ wet weight) of RNA, DNA and protein in the testes of untreated adult guinea-pigs

\begin{tabular}{ccccc}
\hline Body wt & $\begin{array}{c}\text { Wt of testes } \\
(\mathrm{g})\end{array}$ & RNA & DNA & Protein \\
\hline $580 \mathrm{~g}$ & $2.0 \pm 0.15$ & $5.6 \pm 0.5$ & $4.3 \pm 0.35$ & $71 \pm 6$ \\
& $(24)$ & $(24)$ & $(24)$ & $(24)$ \\
$980 \mathrm{~g}$ & $2.5 \pm 0.09$ & $5.4 \pm 0.5$ & $4.1 \pm 0.2$ & $73 \pm 6$ \\
& $(6)$ & $(4)$ & $(4)$ & $(4)$ \\
\hline
\end{tabular}

Values are mean \pm S.E.M., no. of testes in parentheses.

A solution of [methyl- ${ }^{3} \mathrm{H}$ ]thymidine (sp. act. $58.5 \mathrm{Ci} / \mathrm{mmol}$ : ICN Radiochemicals, Inc., Irvine California) was administered by intracardiac injection at a dose of $75 \mu \mathrm{Ci} / 100 \mathrm{~g}$ body weight to 12 guinea-pigs lightly anaesthesized with ether, which were then killed up to $24 \mathrm{~h}$ later. DNA, RNA and protein were isolated and measured as described above and aliquots of each fraction were transferred to scintillation vials and counted.

* Present address: Institute of Comparative Medicine, Baylor College of Medicine/Texas A \& M University, Texas Medical Center, Houston, Texas 77030, U.S.A. 


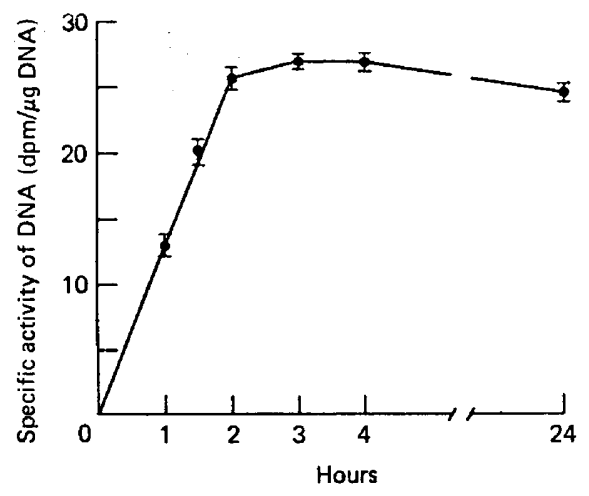

Text-fig. 1. Incorporation of $\left[{ }^{3} \mathrm{H}\right]$ thymidine into testicular DNA at various times after intracardiac injection. Values are mean \pm S.E.M. and for each point there were 4 testes.

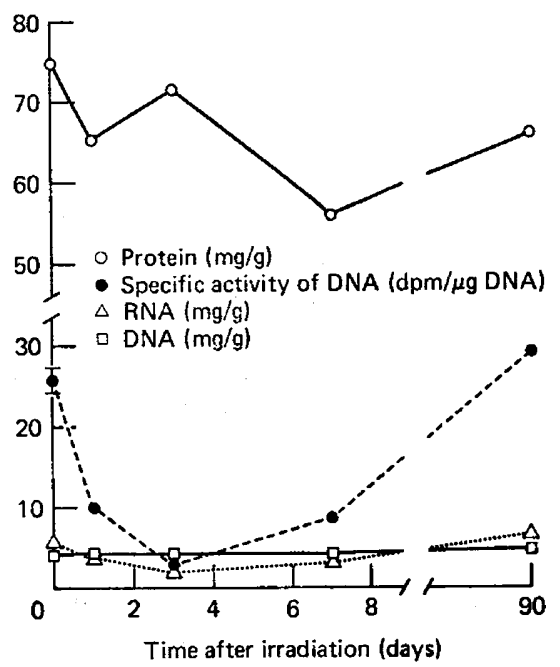

Text-fig. 2. The effects of testicular irradiation ( $400 \mathrm{rads}$ ) on the concentration of various macromolecules ( $\mathrm{mg} / \mathrm{g}$ wet weight of testis) and $\left[{ }^{3} \mathrm{H}\right]$ thymidine incorporation into testicular DNA. Each point is the mean for the 2 testes of each animal.

Incorporation of $\left[{ }^{3} \mathrm{H}\right]$ thymidine into DNA rose linearly until approximately $2 \mathrm{~h}$ after the injection and then plateaued (Text-fig. 1). This time course for incorporation of $\left[{ }^{3} \mathrm{H}\right]$ thymidine was seen only after intracardiac injection of the nucleotide. No consistent pattern of incorporation was seen when the injections were given intravenously or intraperitoneally. The intraperitoneal route may result in variable absorption into the vascular compartment but the reason for the more consistent response after intracardiac administration is not clear. It is possible that a bolus of $\left[{ }^{3} \mathrm{H}\right]-$ thymidine not yet acted upon by the liver or other organs is required to transport the nucleotide across the blood-seminiferous tubule barrier.

Examination of the autoradiographs showed that incorporation of $\left[{ }^{3} \mathrm{H}\right]$ thymidine into the testicular DNA is restricted to the spermatogonia, as has been previously reported by Chowdhury \& Steinberger (1971) and Clermont \& Trott (1969), although the levels of $\left[{ }^{3} \mathrm{H}\right]$ thymidine were high.

Four guinea-pigs were irradiated through a scrotal port with 400 rads and 1, 3, 7 and 90 days later 1 was killed $4 \mathrm{~h}$ after an intracardiac injection of $\left[{ }^{3} \mathrm{H}\right]$ thymidine. The testes were processed separately as described above and the results are given in Text-fig. 2 . Irradiation affects only the cells replicating DNA and it was, therefore, expected that the low dose used in the present study would temporarily inhibit spermatogenesis without affecting other testicular cells (Oakberg, 1975). 
The concentration of RNA decreased then returned to the normal range while the DNA concentration remained constant. However, the rate of $\left[{ }^{3} \mathrm{H}\right]$ thymidine incorporation into DNA fell to extremely low levels by the 3 rd day but had begun to recover by the 7 th day after irradiation. This pattern correlates with the histological and autoradiographic findings. The residual DNA synthesis seen at Day 3 may represent early replenishment of the spermatogonia by a clone resistant to irradiation rather than DNA synthesis in cells other than those involved in spermatogenesis.

Histological or autoradiographic techniques alone do not give a complete evaluation of spermatogenesis. Oakberg (1971) and Huckins (1971) have suggested that the spermatogenic cycle can be divided into the proliferating compartment (early stages) and the differentiating compartment (late stages). Our method evaluates only the proliferating compartment of the spermatogenic cycle. Events in the differentiating compartment can be assessed by histological autoradiographic methods. Although our technique is less demanding and time-consuming than histological or autoradiographic methods and permits assessment of changes in spermatogenesis promptly in a large number of specimens, further work is necessary to prove whether or not this method will lend itself easily to evaluation of spermatogenesis. The technique should simplify investigations into the spermatogenic cycle and particularly the endocrine and pharmacological effects of various agents on spermatogenesis.

\section{S.S.H. is the recipient of an NIH-NICHD Career Development Award (1-K04-HD00108).}

\section{References}

Burton, K. (1956) A study of the conditions and mechanism of the diphenylamine reaction for the colorimetric estimation of deoxyribonucleic acid. Biochem. J. 62, 315-323.

Chowdhury, A.K. \& Steinberger, E. (1971) A radioautography technique for human rat seminiferous tubules mounted in toto. Expl Cell Res. 64, 450-456.

Clermont, Y. \& TrotT, M. (1969) Duration of the cycle of the seminiferous epithelium in the mouse and hamster determined by ${ }^{3} \mathrm{H}$-thymidine and radioautography. Fert. Steril. 20, 805-817.

HuCkins, C. (1971) The spermatogonial stem cell population in adult rats. I. Their morphology, proliferation and maturation. Anat. Rec. 169, 533557.

Hutchinson, W.C. \& MunRo, H.N. (1961) The analysis of nucleic acids. Analyst 86, 768-791.

JANICKI, R. \& LiNGIS, J. (1970) Unabated renal hypertrophy in uninephrectomized rats treated with hydroxyurea. Am. J. Physiol. 219, $1188-1191$.

KWART, A.N. \& CoFFEY, D.S. (1973) Sperm granulomas: an adverse effect of vasectomy. J. Urol. 110, 416-422.

LOHIYA, N.K. \& DixIT, V.P. (1974) Biochemical studies of the testes and sex accessory organs of the desert gerbil after vasectomy. Fert. Steril. 25, 617-620.

Lowry, O.H., Rosebrough, N.J., Farr, A.L. \& RaNDALL, R.J. (1951) Protein measurement with the Folin phenol reagent. $J$. biol. Chem. 193, 265-275.

OAKBERG, E.F. (1971) Spermatogonial stem-cell renewal in the mouse. Anat. Rec. $169,515-532$.

OAKBERG, E.F. (1975) Effects of radiation on the testes. In Handbook of Physiology, Vol. 5, Section 7, Chapter 11, pp. 233-243. Eds R. O. Greep \& E. B. Astwood. Am. Physiol. Soc., Washington, D. C.

Schneider, W.C. (1945) Phosphorus compounds in animal tissues. I. Extraction and estimation of desoxypentose nucleic acid and of pentose nucleic acid. J. biol. Chem. 161, 293-303. 